\title{
Innovation Strategy of 'Silungkang Songket' as the World Heritage
}

\author{
Dessi Susanti ${ }^{1}$, Rose Rahmidani ${ }^{2}$, Armiati $^{3}$ \\ ${ }^{1}$ Dept. of Economics, Faculty of Economics, Universitas Negeri Padang, Padang, Indonesia \\ $\triangle$ (e-mail) dessisusanti@fe.unp.ac.id \\ ${ }^{2}$ Dept. of Economics, Faculty of Economics, Universitas Negeri Padang, Padang, Indonesia \\ $\square$ (e-mail) rose_rahmidani@fe.unp.ac.id \\ ${ }^{3}$ Dept. of Economics, Faculty of Economics, Universitas Negeri Padang, Padang, Indonesia \\ $\triangle$ (e-mail) armiati@fe.unp.ac.id
}

\begin{abstract}
This research is expected to produce a road map of the innovation strategy of silungkang songket and to create the profile of the innovation factors of its to exist nationally and internationally. The data were collected by using observation method, documentation study, interview with silungkang songket businessmen, Minangkabau customary figures and experts from industry and trade office. This research uses a descriptive and qualitative research design. The conclusions of this research are as follows. First, woven fabric or songket silungkang of West Sumatera is a high-value weaving art because it is closely related to the culture and customs of the local community, it is usually used in its customary activities as a cloth, headband, sarong, etc. Second, the innovation strategy of woven silungkang includes product, process and marketing innovation. Third, the silungkang innovation factor is by establishing good relationships with external organizations, such as are government and private institutions through cooperation as the souvenirs supplier for guests in the instituttions' events. Besides, ensuring quality work with th eimplementation of quality control in producing a good quality weaving.
\end{abstract}

Keywords: innovation strategy, innovation factors, silungkang weaving/silungkang songket

\section{Introduction}

Considering the current world of industry has been in the fourth era of economic in which it is very necessary to formulate creative innovation strategies for creative industries to grow and West Sumatra can create a potentially creative industrial center that can be converted in the era of creative economy of the fourth era recently.

It can be seen from the past until now, Silungkang weaving products of West Sumatera are still in great demand and they have support of the government to compete in national and international markets. Surely this can be a necessary learning and input for entrepreneurs of creative products in terms of product innovation strategy that became one of the keys to success in the free market competition that we are going to come into.

Based on the background above this research is influential to do. This research will provide inspiration and ideas for creative entrepreneurs weaving in West Sumatra particularly and generally in Indonesia, related to the significant step and innovation strategies that have been handed down by the Silungkang weaving.

There are several ways that can be taken to produce innovative products. They are: 1) Developing new product attributes consist of adaptation (other ideas or product development), modification (change color, movement, sound, smell, shape and appearance), enlarge (stronger, longer, bigger), minimize (leaner, lighter, smaller), substitution (other material, process, power source), rearrangement (other patterns, other layouts, kompenen), reverses (outer), combination (mixing, assortment, assemblies, combined units, usability, attraction, and ideas), 2) Developing different levels of quality, 3) Developing product models and sizes (product profile) (Kotler \& Keller 2009). 
There are three types of innovation: product innovation, innovation process, and market innovation. First, product innovation has the clearest meaning of producing income. Second, process innovation provides means to maintain and improve quality and to save cost. Thrid, market innovation pay attention to the improvement market target and the chosen market is served well (Jukka, 2008).

This research creates innovation strategy road map and profile of Silungkang woven innovation factor so that it still exists in the national and international weaving arena. The problem in this research is how the creative business innovation strategy of Silungkang weaving from time to time and what factors of silungkang weaving innovation is so that it can still exist in nationally and internationally.

There are eight factors that influence the success of an innovation as follows. Frist, establishing good relationships with outside organizations through communication and willing to accept and adapt external ideas. Second, considering innovation as a long-term effort that requires the involvement of all parties. Third, following established procedures, commitment all parties, especially the employer's boss. Fourth, maintain quality work such as quality control. Fifth, market-oriented actions to keep up with the costumers' needs. Sixth, providing the best service for users. Finally, possessing the presence of certain key individuals as product champions and so on.

\section{Methods}

This research uses descriptive and qualitative research design. Qualitative research is a study that examines socio-cultural phenomena and human interactions that occur naturally, and not in a controlled or laboratory condition (Faisal, 1990).

The stages in this research are: 1) The initial study has tried to trace the story of Silungkang weaving journey then its plan done in order to hold international songket festival, 2) To identify the innovation strategy of Silungkang weaving, 3) To identify the factors of Silungkang weaving innovation so that it can exist nationally and internationally, then in-depth interviews emphasize distinguishing three types of innovation: product innovation, innovation process, and market innovation (Jukka, 2008), 4) Based on the results obtained from the previous research, it can be given recommendation on policy forms and actions that should be made by all stakeholders to make real support for the creative efforts of national weaving in order to compete in product innovation and able to compete in the event of ASEAN Economic Community.

This research is located in Silungkang, Sawah Lunto City in West Sumatera. Location of the research is taken by purposive sampling technique that is area which have creative weaving business and in this case Silungkang become an option because it becomes an area of weaving development in West Sumatera.

The data collection was done by observation, in-depth interview (structured and unstructured). This study used secondary data and primary data. The secondary data were collected by using observation method and documentation study on documents in the Department of Industry and Trade, BPS and other related institutions. While primary data was collected through interviews with respondents (Silungkang weaving entrepreneurs), Minangkabau customary figures known as tungku tigo sajarangan; members of cleric, ancestor and inteligent generation and expert from industry and trade office. The determination of research respondents for members of cleric, ancestor and inteligent generation and expert of industry and trade agencies conducted with snowball sampling technique (Iskandar, 1990).

The data analysis was done by using qualitative analysis model which suggests that the data analysis in qualitative research is done continuously and interactively until thoroughly so that the data is saturated. Activities in data analysis are data reduction, display data and conclusion drawing/ verification (Miles \& Michael, 2007). 


\section{Results and Discussion}

Until now weaving in Silungkang still passed down from generation to generation. The development of traditional silungkang songket experience ups and downs. One of them is the entry of Non-Machinery Weaving Equipment (NMWE) and Machine Weaving Equipment (MWE). It affects the traditional of silungkang songket. Formerly the traditional of silungkang songket equipment was gedogan around the year 1945, in which weavers sit on the floor and waist tied.

In accordance with the development of the times, the community began to revive the traditional of silungkang songket by modifying the traditional equipment raised to NMWE which until now has been used by the silungkang weavers. This Non-Engine Weaving Tool has been used around 1975 .

NMWE was introduced by the colonial government in the early 1930s. There are several modifications, including on the weaver's seat bench, and the gun is raised and lowered with a footrest on the pedal attached to the carok. About 5 years later, the number of NMWE increased fourfold. Production grows rapidly and men also weave to meet market demand (Achjadi et al, 2013: 9).

Based on the decription above, it can be concluded that Silungkang community has been using NMWE that has been modified as a loom to weave the Silungkang songket fabric. the production of silungkang woven cloth that grows rapidly and it is visible from the increasing market demand so that weavers are not only from the women but also the men.

Silungkang community is still using NMWE to make traditional silungkang songket, where NMWE it self is a modification of traditional looms adapted to the weaver's own silungkang.

To produce a variety of songket cloth and innovation, for the next development the craftmens of silungkang songket blend ikat techniques with songket technique. In addition, for cotton yarn, the material used is also taken from silk yarn with ornate yarn or colored cotton yarn.

In the past, coloring of warp yarns was done traditionally. The procedure, before the warp yarn is colored, the yarn must be cleaned from the dirt and other elements that will block the entry of dye. Then, the yarn is given a bleach agent (soda ash). The substance can be obtained easily in chemical stores or pharmacies. After that, the yarn was split into sections then dyed with the necessary colors. This proves that Silungkang weaving craftsmen are familiar with modern ways of bleaching materials.

Along with the development of the times and tastes of the market turned out in the coloring, silungkang woven back to follow the old pattern, it means on the use of colors back to natural or natural colors as a coloring material, it is expected to be one of the innovations to attract consumers, recall the booming term back to nature and it is also at the same time become one source of competitive advantage of fabric product of silungkang origin.

Silungkang fabric has advantages on the motive. Another specialty is in its variety. There are ikat songket, batabua songket, full, two thread, and wide scarf songket. This uniqueness is the reason of songket Silungkang buyers come from another country, like Malaysia and Singapore.

The weaving motif arises from the creation and imagination of the weaving craftsmen, which means that weaving is closely related to the artistic value arising from people who have high artistic talents.

Silungkang Songket weaving craftsmen not only produce one particular kind of songket, such as sarung and or cloth. However, it has expanded into other types of products, such as wall picture, tablecloth, picture tapestry, women's shirt, bed cover, chair suit, rug cushion, scarf, kitchen wipe, handkerchief, shirt material ("hem"), and tussor (diagonal weaving material).

These handicraft products are innovative and Creative programs through the Nusantara Collaboration.There are many types of songket that exist, some of them have made new innovations 
as one of the strategies in reaching the percentage of the market, everything is still able to maintain the authenticity of the resulting motive despite being adapted to the times.

The value of beauty is reflected in the motive of the decoration made in such a way, so that emits the beauty. Meanwhile, the value of diligence, precision, and patience is reflected in the manufacturing process. Without these values it is impossible to realize a good songket weaving.

The development of Social media also turns to the way of sale used by the craftsmen in marketing their traditional fabrics by starting to have an account on Facebook / blog. These media becomen one of the new marketing methods for them in which the effectiveness of the social media method still needs more deepening to see the impact on the sale of fabric origin of silungkang.

Innovation factor of silungkang woven among others is to establish good relationship with outside organization through communication and willing to accept and adapt the ideas from outside. The next innovation factor is quality work such as quality control.

Because of the uniqueness and diversity of motifs and historical values attached to the craft which is the local wisdom of the community of Sawah Lunto city, since centuries ago, so the craft of silungkang songket can wriggle the society economy and it is able to go in the international markets.

The expected output from this research is to produce a road map of the innovation strategy of silungkang woven and produce profile of innovation factors of Silungkang woven so that it can still exist nationally and internationally.

Figure 1 Road map innovation strategy of silungkang songket

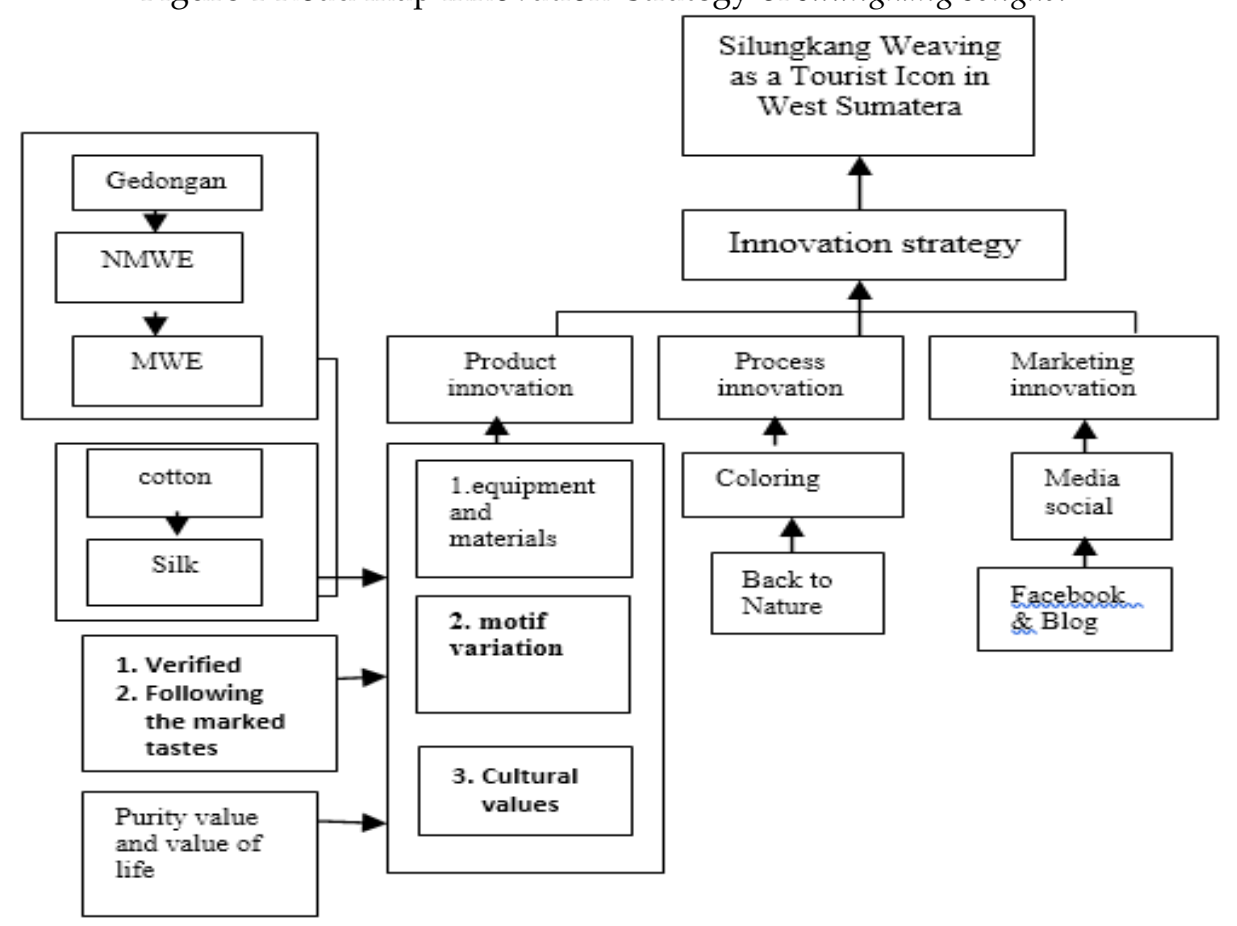

\section{Conclusions}

This study aims to produce a road map of the innovation strategy of silungkang songket and to create the profile of the innovation factors for it to exist nationally and internationally. The data were collected by using observation method, documentation study, interview with silungkang songket businessmen, Minangkabau customary figures and experts from industry and trade office. This research uses a descriptive and qualitative research design. 
The conclusions of this research are as follows. First, woven fabric or songket silungkang of West Sumatera is a high-value weaving art because it is closely related to the culture and customs of the local community, it is usually used in its customary activities as a cloth, headband, sarong, etc.

Second, the innovation strategy of woven silungkang includes product, process and marketing innovation.

a) Product innovation which consists of equipment and materials, design, and cultural values. For equipment and materials, the increased use of gedogan due to the emergence of non-machine looms and machine weaving tool, recently. Silungkang used to only used $100 \%$ cotton as the material but now silnungkang have used various materials based on market demand such as silk. In regards of design, silungkang used decorative ornaments weaving silungkang has an advantage on the motif. The motif and variety of weaving evolve over time and responding to the market needs. For cultural values, the value of purity and other that become the reference in the daily life of society that exist in weaving silungkang provide its own power to emit the beauty of weaving and this becomes the specialty of weaving Silungkang.

b) Innovation Process, techniques of weaving the songket, along with the styles and market tastes development which are translated into the dyeing, the return to the old pattern means the use of natural dye ingredients.

c) Marketing innovation, through social media development which has an impact on marketing strategy used by the silungkang businessmen by utilizing Facebook or web blog.

Third, the silungkang innovation factor is by establishing good relationships with external organizations, such as are government and private institutions through cooperation as the souvenirs supplier for guests in the instituttions' events. Besides, ensuring quality work with th eimplementation of quality control in producing a good quality weaving.

\section{Acknowledgments}

The authors express their graditute to the Directorate General Higher Educationfor funding funding the study.

\section{References}

Faisal, S. (1990). Penelitian Kualitatif: Dasar-dasar dan Aplikasi. Malang: Yayasan Asih Asah Asuh (YA3 Malang).

Iskandar. (2009). Metodologi Penelitian Pendidikan dan Sosial. Jakarta: Gaung Persada Press.

Jukka, O. (2008). Management of innovation networks: a case study of different approaches. European Journal of Innovation Management, 11(1), 51 - 86

Kotler, P., \& Keller, K. L. (2009). Marketing Management. New Jersey: Prentice Hall, Inc.

Miles, M. B., \& Michael, A., H. (2007). Analisis Data Kualitatif. Buku Sumber tentang Metode-Metode Baru. Jakarta: Universitas Indonesia Press. 